Supplement of Clim. Past, 11, 1027-1047, 2015

http://www.clim-past.net/11/1027/2015/

doi:10.5194/cp-11-1027-2015-supplement

(C) Author(s) 2015. CC Attribution 3.0 License.

(c) (i)

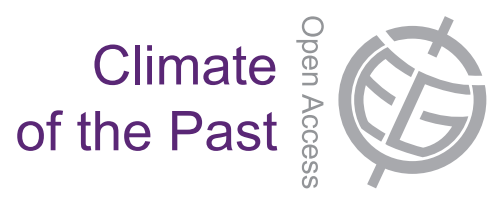

Supplement of

\title{
A collection of sub-daily pressure and temperature observations for the early instrumental period with a focus on the "year without a summer" 1816
}

Y. Brugnara et al.

Correspondence to: Y. Brugnara (yuri.brugnara@giub.unibe.ch)

The copyright of individual parts of the supplement might differ from the CC-BY 3.0 licence. 
Table S1: Data sources and references for the land records. An asterisk marks the records that were digitised during the preparation of this paper. Most of this digitisation (with the only exception of Avignon) was carried out at the Institute of Geography of the University of Bern. Contemporary magazines and newspapers are written in italics. When original manuscripts were digitised, the archive, library or institution which provided copies of the documents is indicated.

$$
\text { Station }
$$

Aarau*

Albany*

Althorp*

Armagh

Avignon*

Barcelona

Barnton*

Bologna*

Boston*

Brunswick*

Cadíz

Calton Hill*

Cambridge*

Coimbra*

Cracow*

Derby*

Düsseldorf*

Exeter

Gdansk

Geneva

Göteborg*

Haarlem

Härnösand*

Hohenpeissenberg

Karlsruhe

London

Lviv*

Madrid

Milan

Natchez*

New Bedford* Source

Archiv der Medizin, Chirurgie und Pharmazie

The North American Review and Miscellaneous Journal

The Quarterly Journal of Science and the Arts

International Surface Pressure Databank

Médiathèque d'Avignon

University of Barcelona

The Edinburgh Magazine and Literary Miscellany

Library of the Astronomy Department, University of Bologna

Philosophical Magazine

National Climatic Data Center, Asheville, NC

Project IMPROVE

The Edinburgh Magazine and Literary Miscellany

The North American Review and Miscellaneous Journal

Jornal de Coimbra

Jagiellonian University

The Annals of Philosophy

Amtsblatt für den Regierungsbezirk Düsseldorf

Project ACRE

University of Gdańsk

University of Bern

National Archives, Stockholm

KNMI-Royal Netherlands Meteorological Institute

National Archives, Stockholm

DWD-Deutscher Wetterdienst

Karlsruhe Institute of Technology

CRU, University of East Anglia

Lemberger Zeitung

Universidad de Extremadura

Università degli Studi di Milano

National Climatic Data Center, Asheville, NC

National Climatic Data Center, Asheville, NC
References and Notes

Volumes 1-3

Volume 1

Volumes 1-4

Yin et al. 2008

Digitised by G. Pichard (Université Aix-Marseille)

Rodríguez et al. (2001)

Volumes 77-80

Volumes 47-51

Barriendos et al. (2002)

Volumes 80-81

Volumes 1-3

Volumes $7-10$

Hess (1982)

Volume 11

Years 1816-1817

http://www.met-acre.org

Filipiak and Mietus (2010)

Auchmann et al. (2012)

Available on KNMI's website

Winkler (2006)

Cornes et al. (2012a)

Years 1815-1817

Domínguez-Castro et al. (2014

Maugeri et al. (2002a b, 2004) 
Table S1: (continued)

\begin{tabular}{|c|c|c|}
\hline Station & Source & References and Notes \\
\hline New Haven* & National Climatic Data Center, Asheville, NC & \\
\hline Nuuk* & National Archives, Copenhagen & \\
\hline Padua* & Library of the Astronomical Observatory, Padua & Camuffo et al. (2006) \\
\hline Paris (a) & University of Barcelona & Cornes et al. (2012b) \\
\hline Paris $(b) *$ & Annales de Chimie et de Physique & Volumes $1-6$ \\
\hline Prague* & Masaryk University & \\
\hline Quebec City & Project ACRE & http: //www.met-acre.org \\
\hline Rochefort & Météo-France & Bleuse $(2010)$ \\
\hline Salem & CRU, University of East Anglia & van der Schrier and Jones (2008); avail. on CRU's website \\
\hline Stockholm & Bolin Centre, Stockholm University & Moberg et al. (2002); available on Bolin Centre's website \\
\hline Turin & SMI-Società Meteorologica Italiana, Turin & Di Napoli and Mercalli $(2008)$ \\
\hline Umeå* & National Archives, Stockholm & \\
\hline Uppsala & Uppsala University & Bergström and Moberg (2002) \\
\hline Valencia & Justus Liebig University of Giessen & Domínguez-Castro et al. (2014) \\
\hline Växjö* & National Archives, Stockholm & \\
\hline Vienna & ZAMG-Central Institute for Meteorology and Geodynamics, Vienna & \\
\hline Ylitornio & University of Helsinki & Klingbjer and Moberg (2003); Holopainen (2006) \\
\hline Žitenice & Masaryk University & Brázdil et al. (2007) \\
\hline Zwanenburg & KNMI-Royal Netherlands Meteorological Institute & Available on KNMI's website \\
\hline
\end{tabular}


Table S2: List of sub-daily pressure land records for the period 1815-1817 that are not included in the described collection but are listed in catalogues of archives/libraries, mentioned in the literature or published by contemporary magazines.

\begin{tabular}{|c|c|c|c|}
\hline Station & Country & Period & Location of the manuscripts (if known) / Name and volumes of the magazine \\
\hline Arnhem & Netherlands & $1782-1819$ & KNMI-Royal Netherlands Meteorological Institute, De Bilt, Netherlands (copies) \\
\hline Baltimore, MD & U.S.A. & $1817-1824$ & Observations made in 1817 published in Brantz $(1818)$ \\
\hline Benefield & England & $1815-1858$ & National Meteorological Archive, Exeter, U.K. \\
\hline Berlin & Germany & $1774-1826$ & Berlin-Brandenburg Academy of Sciences and Humanities, Berlin, Germany \\
\hline Birmingham & England & $1793-1830$ & Birmingham Archives and Heritage, Birmingham, U.K. \\
\hline Carlisle & England & $1801-1824$ & \\
\hline Charlottesville, VA & U.S.A. & $1802-1816$ & Coolidge Collection, Massachusetts Historical Society, Boston, MA, U.S.A. \\
\hline Chennai (Madras) & India & $1796-1824$ & The Royal Society's Library, London, U.K. \\
\hline Cookstown & Ireland & $1817-1853$ & National Meteorological Archive, Exeter, U.K. \\
\hline Copenhagen & Denmark & $1767-1845$ & \\
\hline Cork & Ireland & $1799-1823$ & National Meteorological Archive, Exeter, U.K. \\
\hline Delft & Netherlands & $1777-1829$ & KNMI-Royal Netherlands Meteorological Institute, De Bilt, Netherlands (copies) \\
\hline Dresden & Germany & $1812-1829$ & \\
\hline Dudson & England & $1813-1817$ & Library of Birmingham, U.K. \\
\hline Falun & Sweden & $1803-1828$ & National Archives, Stockholm, Sweden \\
\hline Florence & Italy & from 1813 & Osservatorio Ximeniano, Florence, Italy \\
\hline Gävle & Sweden & $1817-1825$ & National Archives, Stockholm, Sweden \\
\hline Gordon Castle & Scotland & $1781-1821$ & National Meteorological Archive, Exeter, U.K. \\
\hline Guilsborough & England & $1815-1863$ & National Meteorological Archive, Exeter, U.K. \\
\hline Hedvigsfors & Sweden & $1810-1819$ & National Archives, Stockholm, Sweden \\
\hline Helsinki & Finland & $1780-1819$ & National Archives, Stockholm, Sweden \\
\hline Holywell & Wales & $1793-1832$ & National Meteorological Archive, Exeter, U.K. \\
\hline Hudiksvall & Sweden & $1813-1861$ & National Archives, Stockholm, Sweden \\
\hline Kaliningrad & Russia & $1815-1817$ & Published in Bessel $(1816,1817)$ \\
\hline Kangasniemi & Finland & $1810-1815$ & National Archives, Helsinki, Finland \\
\hline Kinfauns Manse & Scotland & $1816-1820$ & National Archives of Scotland, Edinburgh, U.K. \\
\hline Lancaster & England & $1817-1820$ & \\
\hline London (Greenwich) & England & $1811-1851$ & National Meteorological Archive, Exeter, U.K. \\
\hline London (Holborn) & England & $1815-1817$ & Published in The London Medical Repository, volumes 3-9 \\
\hline London (Kew) & England & $1773-1840$ & National Meteorological Archive, Exeter, U.K. \\
\hline London (Stanmore) & England & 1817 & Published in Annals of Philosophy, volumes 10-11 \\
\hline London (Strand) & England & $1815-1817$ & Published in Philosophical Magazine, volumes $45-51$ \\
\hline
\end{tabular}


Table S2: (continued)

\begin{tabular}{|c|c|c|c|}
\hline Station & Country & Period & Location of the manuscripts (if known) / Name and volumes of the magazine \\
\hline London (Syon House) & England & $1782-1822$ & National Meteorological Archive, Exeter, U.K. \\
\hline London (Tottenham) & England & $1797-1841$ & National Meteorological Archive, Exeter, U.K. \\
\hline London (Walthamstow) & England & $1816-1817$ & Published in Philosophical Magazine, volumes $48-51$ \\
\hline Lund & Sweden & from 1740 & Lund University Library, Lund, Sweden; described by Bärring et al. $(1999)$ \\
\hline Maastricht & Netherlands & $1802-1833$ & \\
\hline Manchester & England & $1794-1818$ & \\
\hline Mikkeli & Finland & $1816-1821$ & National Archives, Helsinki, Finland \\
\hline Modbury & England & $1788-1822$ & National Meteorological Archive, Exeter, U.K. \\
\hline Mongewell & England & $1770-1823$ & The Royal Society's Library, London, U.K. \\
\hline Montdidier & France & $1783-1869$ & Bibliothèque Nationale de France, Paris, France \\
\hline New Malton & England & $1816-1820$ & \\
\hline Newcastle-upon-Tyne & England & $1802-1833$ & Newcastle Literary and Philosophical Institute, Newcastle-upon-Tyne, U.K. \\
\hline Pavia & Italy & $1808-1815$ & Published in Giornale di Fisica, Chimica e Scienze Naturali, volumes 1-9 \\
\hline Penzance & England & $1807-1827$ & \\
\hline Perth & Scotland & $1813-1816$ & National Archives of Scotland, Edinburgh, U.K. \\
\hline Plymouth & England & $1814-1817$ & Published in Annals of Philosophy, volumes $3-8$ \\
\hline Poitiers & France & $1792-1819$ & Médiathèque F. Mitterrand, Poitiers, France \\
\hline Regensburg & Germany & $1815-1816$ & Published in Journal für Chemie und Physik, volumes 13-18 \\
\hline Richmond & England & $1815-1817$ & Published in The London Medical Repository, volumes 3-9 \\
\hline Schiedam & Netherlands & $1806-1841$ & KNMI-Royal Netherlands Meteorological Institute, De Bilt, Netherlands (copies) \\
\hline Strängnäs & Sweden & $1786-1843$ & National Archives, Stockholm, Sweden \\
\hline Strömbacka & Sweden & $1816-1826$ & National Archives, Stockholm, Sweden \\
\hline Sunbury-on-Thames & England & $1795-1839$ & National Meteorological Archive, Exeter, U.K. \\
\hline Thetfort & England & $1817-1837$ & \\
\hline Toulouse & France & 1809-1899 & Archives du canal du midi, Voies navigables de France, Toulouse, France \\
\hline Udine & Italy & $1803-1842$ & \\
\hline
\end{tabular}




\section{Bibliography}

Auchmann, R., Brönnimann, S., Breda, L., Bühler, M., Spadin, R., and Stickler, A.: Extreme climate, not extreme weather: the summer of 1816 in Geneva, Switzerland, Clim. Past, 8, 325-335, 2012.

Barriendos, M., Martín-Vide, J., Peña, J. C., and Rodríguez, R.: Daily meteorological observations in Cádiz-San Fernando. Analysis of the documentary sources and the instrumental data content (1786-1996), Climatic Change, 53, 151-170, 2002.

Bärring, L., Joensson, P., Achberger, C., Ekström, M., and Alexandersson, H.: The Lund instrumental record of meteorological observations: reconstruction of monthly sea-level pressure 1780-1997, Int. J. Climatol., 19, 1427-1443, 1999.

Bergström, H. and Moberg, A.: Daily air temperature and pressure series for Uppsala (1722-1998), Climatic Change, 53, 213-252, 2002.

Bessel, F. W.: Astronomische Beobachtungen auf der Königlichen Universitäts-Sternwarte in Königsberg, Zweite Abt., Nicolovius, Königsberg, 1816.

Bessel, F. W.: Astronomische Beobachtungen auf der Königlichen Universitäts-Sternwarte in Königsberg, Zweite Abt., Nicolovius, Königsberg, 1817.

Bleuse, P.: La série climatologique ancienne de Rochefort, La Météorologie, 68, 41-49, 2010.

Brantz, L.: Meteorological Observations; Made in the Vicinity of Baltimore, During the Year 1817, W. Gwynn, Office of the Federal Gazette, Baltimore, MD, 1818.

Brázdil, R., Řezníčková, L., Valášek, H., and Kotyza, O.: Early instrumental meteorological observations int the Czech lands III: František Jindřich Jakub Kreybich, Žitenice, 1787-1829, Meteorologický Časopis, 10, 63-74, 2007.

Camuffo, D., Cocheo, C., and Sturaro, G.: Corrections of systematic errors, data homogenisation and climatic analysis of the Padova pressure series (1725-1999), Climatic Change, 78, 493-514, 2006.

Cornes, R. C., Jones, P. D., Briffa, K. R., and Osborn, T. J.: A daily series of mean sea-level pressure for London, 1692-2007, Int. J. Climatol., 32, 641-656, 2012a. 
Cornes, R. C., Jones, P. D., Briffa, K. R., and Osborn, T. J.: A daily series of mean sea-level pressure for Paris, 1670-2007, Int. J. Climatol., 32, 1135-1150, 2012b.

Di Napoli, G. and Mercalli, L.: Il clima di Torino: tre secoli di osservazioni meteorologiche, SMS, Turin, 2008.

Domínguez-Castro, F., Vaquero, J., Rodrigo, F., Farrona, A., Gallego, M., García-Herrera, R., Barriendos, M., and Sanchez-Lorenzo, A.: Early Spanish meteorological records (1780-1850), Int. J. Climatol., 34, 593-603, 2014.

Filipiak, J. and Miętus, M.: History of the Gdańsk pre-instrumental and instrumental record of meteorological observations and analysis of selected air pressure observations, in: The Polish Climate in the European Context: An Historical Overview, edited by Przybylak, R., Majorowicz, J., Brázdil, R., and Kejna, M., pp. 267-293, Springer, Dordrecht, 2010.

Hess, M., ed.: Results of studies of the climatological station of the Jagiellonian University in Cracow, vol. 77 of Zeszyty Naukowe UJ Prace Geograficzne, Panstwowe Wydawnictwo Naukowe, Cracow, 1982.

Holopainen, J.: Reconstructions of past climates from documentary and natural sources in Finland since the 18th century, Ph.D. thesis, Department of Geology D9, Yliopistopaino, Helsinki, 2006.

Klingbjer, P. and Moberg, A.: A composite monthly temperature record from Tornedalen in northern Sweden, 1802-2002, Int. J. Climatol., 23, 1465-1494, 2003.

Maugeri, M., Buffoni, L., and Chlistovsky, F.: Daily Milan temperature and pressure series (1763-1998): history of the observations and data and metadata recovery, Climatic Change, 53, 101-117, 2002a.

Maugeri, M., Buffoni, L., Delmonte, B., and Fassina, A.: Daily Milan temperature and pressure series (1763-1998): completing and homogenising the data, Climatic Change, 53, 119-149, 2002b.

Maugeri, M., Brunetti, M., Monti, F., and Nanni, T.: Sea-level pressure variability in the Po Plain (1765-2000) from homogenized daily secular records, Int. J. Climatol., 24, 437-455, 2004.

Moberg, A., Bergström, H., Krigsman, J. R., and Svanered, O.: Daily air temperature and pressure series for Stockholm (1756-1998), Climatic Change, 53, $171-212,2002$.

Rodríguez, R., Barriendos, M., Jones, P., Martín-Vide, J., and Pena, J.: Long pressure series for Barcelona (Spain). Daily reconstruction and monthly homogenization, Int. J. Climatol., 21, 1693-1704, 2001.

van der Schrier, G. and Jones, P.: Daily temperature and pressure series for Salem, Massachusetts (1786-1829), Climatic Change, 87, 499-515, 2008.

Winkler, P.: Hohenpeißenberg 1781-2006 - das älteste Bergobservatorium der Welt, Deutscher Wetterdienst, Offenbach am Main, 2006.

Yin, X., Gleason, B., Compo, G., Matsui, N., and Vose, R.: The International Surface Pressure Databank (ISPD) land component version 2.2, Tech. rep., National Climatic Data Center, Asheville, NC, available from ftp://ftp.ncdc.noaa.gov/pub/data/ispd/doc/ISPD2, 2008. 